\title{
ART(E)BIOLOGIA NA NATUREZA E OUTRAS MANEIRAS DE PENSAR A EDUCAÇÃO
}

\section{ART AND BIOLOGY IN NATURE AND OTHER WAYS OF THINKING EDUCATION}

\begin{abstract}
Carlos Augusto Silva e Silva Doutorado em andamento em Educação pela Universidade Federal de Rondônia - UNIR. Técnico em Assuntos Educacionais no Instituto Federal de Rondônia.

Porto Velho, Rondônia-RO carlosaugusto.s02@gmail.com
\end{abstract}

Maria dos Remédios de Brito Pós-doutora em Filos ofia da Educação pela Universidade Estadual de Campinas. Professora na Universidade Federal do Pará - UFPA. Belém, Pará - PA. mrdbrito@hotmail.com

Resumo: O texto provoca um entre art( e)biologia na tentativa de atritar a ciência como um modo de conhecimento fincado em normas específicas, assim como na educação, com o intuito de pensar em conjunto, entre. Para a produção da pesquisa utilizou-se ligações por entre imagens, escritas e experimentações performáticas do corpo na natureza, percurso este que instiga um biólogo que também está como artista, professor, aluno, pesquisador, entre outros, que atravess a sua(s) vida(s) e se envereda por entre cachoeiras e cavernas. O esforço teórico percorreu por inspirações da filosofia de Gilles Deleuze e Félix Guattari e por artistas e biólogos da educação e do ensino de ciências que vagueiam e pensam em meio a estas conexões. Para efeitos didáticos, o corpo textual foi organizado em aberturas, além de introduzir a problemática em questão, que são, no entanto, transponíveis e de livre des locamento entre elas a descrição, o percurso metodológico utilizado para a produção das imagens na natureza. Em sequência, as experimentações que produziram, além das imagens, uma escrita sensível e conceitual a partir das inspirações no percurso da investigação em questão. Por fim, ousamos argumentar, a partir das experimentações em criação, sobre uma educação alegre que faça a biologia sorrir a partir da arte sem a necessidade de substituir saberes, mas, quem sabe, compor junto por uma art(e)biologia que possibilite biólogos, artistas, professores, alunos e pesquisadores rirem na educação.

Palavras-chave: Ciências. Educação. Arte. Filosofia da diferença.

\begin{abstract}
The text provokes A between art and biology in an attempt of attrict science as a way of knowledge embedded in specific norms, as well as in education, in order to think together, between. For the production of the research, links were used between images, writings and performatic experiments of the body in nature, a path that instigates a biologist who is also an artist, teacher, student, researcher, among others, who crosses his life(s) and wander through waterfalls and caves. The theoretical effort went through inspirations of Gilles Deleuze and Félix Guattari's philosophy, artists and biologists of education and the teaching of science that walk and think through these connections. For didactic purposes, the textual body was organized into openings, in addition of introducing the issue in question, which is, however, transposable and freely displaced between them, the description of the methodological path used for the production of images in nature. In sequence, the experiments that produced, in addition to the images, a sensitive and conceptual writing from the inspirations in the course of the searching in question. Finally, we dare to argue, based on experiments in creation, about a joyful education that makes biology smile from the starting point of art without the need to replace knowledge, but, compose together with an art and biology that enables biologists, artists, teachers, students and researchers laugh in education.
\end{abstract}

Keywords: Science. Education. Art. Philosophy of difference.

Para citar - (ABNT NBR 6023:2018)

SILVA, Carlos Augusto Silva e; BRITO, Maria dos Remédios de. Art(e)biologia na natureza e outras maneiras de pensar a educação. Eccos - Revista Cientifica, São Paulo, n. 54, p. 1-22, e17751, jul./set. 2020. Disponível em: https://doi.org/10.5585/eccos.n54.17751. 


\section{Introdução}

Atualmente, a relação entre ciência e arte se tornou uma discussão em destaque no campo da Educação em Ciências. Problematizações de professores, pesquisadores e cientistas de formação, sobretudo biólogos, buscam na arte a possibilidade de arrastar a ciência para outro lugar que pouco tem a ver com o cientificismo imbuído numa verdade universal e racional (CAMPOS, 2003; HISSA, 2011; DIAS; ANDRADE; DE AMORIM, 2012; SILVA, 2018), assim como, hoje, $\operatorname{artistas}^{1}$ rompem a membrana da arte clássica e utilizam a ciência para compor seus processos de criação. São biólogos, artistas, professores e pesquisadores que reinventam modos de pensar a ciência e a arte, fazendo, nem que seja por alguns instantes, a fragmentação dos saberes passar, repensando o "ou" que delimita: arte ou ciência.

Com Deleuze e Guattari (2012), faz-se repensar sobre tal conjuntura "ou” que confere divisões, nas quais as artes ou ciências se emolduram, estabelecendo-se o pensamento binário: artes ou biologias, arte/emotiva, biologia/verdade, sombreando as metamorfoses e os hibridismos. Neste mesmo sentido, os autores maquinam diálogos referentes à terminação "é" que produz um ser identitário, definindo uma única e cristalizada essência. No entanto, esses mesmos pensadores subvertem tais maniqueísmos e identidades, oportunizando o "e"2, afirmando que "[...] há nesta conjunção força suficiente para sacudir e desenraizar o verbo ser" (DELEUZE; GUATTARI, 2012, p.48) que traz possibilidades de diferentes conexões transitando pelos meios, pois o devir está no entre: é o entre que "[...] se encontra sempre no meio, entre as coisas, inter-ser, intermezzo" (DELEUZE; GUATTARI, 2012, p. 48). Então, na arte e biologia há potência para substituir o "É" pelo "E”, o "Ser" pelo "Devir".

O que há no intermezzo arte e biologia? Heterogeneidades? Forças? Acontecimentos? Como traçar itinerários entre blocos de sensações e functivos, alcançando o entre as coisas? Ao pensar sobre artes e biologias, bosquejam-se pensamentos inspirados em Dias e Rodrigues: "estariam essas conjunções ressoando apenas pelas somas (arte + ciências), consensos (arte $=$ ciência), exclusões (arte > ciência - arte < ciência)? E se... e...?" (2012, p.1).

Somas, consensos e exclusões de artes e biologias, artistas e biólogos. O que se pode extrair desse atravessamento? Vazamentos? A junção das artes e biologias carregam múltiplas forças, produzem variações infinitas que desestabilizam suas próprias essências. Ao fissurar os muros que delimitam as fronteiras pode-se criar artefatos artísticos e biológicos, novos modos de ser, escrever, ouvir, pensar, ver e estar no mundo. Torna-se uma nova postura política na educação que não falam do novo, mas, que se se fissuram a ele. 
Dessa maneira, os movimentos acontecem empreendendo um processo de constantes recriações e fabulações móveis. Portanto, as artes e as ciências inclinam-se para outras possibilidades de incitarem corpos que, além de inventar, buscam aventurar-se fora das trilhas, sem fincar-se em uma identidade aglutinada.

Quem pode ser um biólogo? Quem pode ser artista? Na verdade, não precisamos de mais um modelo e nem pretendemos propor um dentre os que existem: biólogo artista, biólogo pesquisador, artista pesquisador, entre outros. Corpos que não se engendram na arte ou na biologia, mas, buscam para si movimentos experimentativos na criação de novas configurações de mundos, olhares, viver e de ser (DELEUZE, 2007).

No entanto, constantemente, estes cientistas/artistas que decidem pelo novo e o desvencilhamento são tosquiados por uma censura que os definem como desviantes e/ou vagabundos, como assim diz Deleuze e Guattari (2012, p. 24):

Você será significante e significado, intérprete e interpretado — senão será des viante. Você será sujeito e, como tal, fixado, sujeito de enunciação rebatido sobre um sujeito de enunciado - senão você será apenas um vagabundo.

Esses atravessamentos e vazamentos entre biologia e arte nada têm a ver com a pedagogização da ciência através da arte que se torna fundamentação para pensar a ciência de maneira mais lúdica ou leve e, com isso, sempre estabelecendo a arte como algo inferior ao conhecimento científico. Ora, a arte cria perceptos e afectos ${ }^{3}$, a ciência cria fuctivos, mas isso não deixa de colocar esses saberes em ligações preferenciais (DELEUZE; GUATTARI, 2013).

Portanto, cabe ressaltar que não pretendemos combater o pensamento científico e coroar os afetos e perceptos artísticos, mas pensar num combate-entre, pois segundo Deleuze "[...] o combate-entre é o processo pelo qual uma força se enriquece ao se apossar de outras forças somando-se a elas num novo conjunto, num devir" (1997, p. 170). Nem arte e nem ciência, mas arte e biologia que surgem a partir da potencialidade do entre.

Negar e criticar a biologia que esmaga a diferença é fácil; difícil é compor com ela, a partir dela. Colocar fermento na massa criativa e vê-la crescer e não apenas amassar aquilo que já foi amassado diversas vezes: reinventar a biologia, reinventar a arte, reinventar as coisas.

É propriamente a inquietação dessa relação entre ciência e arte, mais precisamente, biologia e arte, que constitui o objeto do pensamento que povoa este ensaio. Para tal, produzimos um ensaio fotográfico e performático denominado art(e)biologia, um processo que incentiva, através de uma leitura experimental no e com o corpo, a criação de novas possibilidades de pensar a biologia e a arte evocando e sentindo ecos na natureza, emergindo, 
juntamente ao leitor, num bloco de sensações em que envolve muito mais do que arte ou biologia, mas sim, art(e)biologia.

Trata-se, portanto, de um estudo em que seu corpo construtivo advém por experimentações, em um processo no qual o exercício do não linear é um convite à abertura do pensamento e das sensações, utilizando-se da filosofia para compor esse arcabouço transdisciplinar. Por fim, os processos experimentativos, bem como o próprio texto, não precisam ser interpretados, mas maquinados: maquinem de enésimas maneiras, se desejem.

Para efeitos didáticos, o corpo textual foi organizado em três enfoques experimentativos, no entanto, transponíveis, e de livre deslocamento entre eles: 1) Experimentações e produções de imagens na natureza traz apontamentos descritivos e metodológicos sobre a produção das experimentações performáticas e fotográficas na natureza; 2) Art(e)biologia apresenta, além das imagens, todo um arcabouço conceitual que envolve a trama dos processos criativos que atravessam biologia e arte a partir da filosofia da diferença de Deleuze e Guattari; 3) Alguns apontamentos finais para a educação pensando a educação a partir da vida, e que argumenta sobre uma educação alegre e uma biologia que rir.

\section{Experimentações e produções de imagens na nature $\mathbf{z a}^{4}$}

Um biólogo, que também é um pouco professor, artista e pesquisador, retorna ao local onde fez diversas experimentações biológicas, porém, com outra proposta, com outras experimentações, como outro biólogo. Tratou-se de sentir o lugar, no sentido de produzir outras conexões com a natureza, com a biologia e consigo.

As experimentações foram produzidas e capturadas no caminho e na Caverna/Cachoeira do Km 30 (localizada no Ramal Novo Xingu, a $30 \mathrm{~km}$ da cidade de Altamira-Pará) e na Caverna da Planaltina (a $3 \mathrm{~km}$ de Brasil Novo e a $45 \mathrm{~km}$ de Altamira, ambas no mesmo estado). Tanto as cavernas quanto as cachoeiras destes lugares atraem pesquisadores e desbravadores em busca de locais pouco degradados, também por conta da sua biodiversidade.

No intuito de transformar as imagens produzidas nas experimentações foram acionadas algumas intervenções tecnológicas como o software Adobe Photoshop e Adobe Lightroom Classic CC, no sentido de inserir efeitos não tão comuns e brincar com os elementos, cores e texturas. Nessas edições exploramos novas experimentações após a captura das imagens fotográficas, no sentido de "[...] propor fotografias como espaço de criação, sobreposição de realidade, encenação e fantasia" (LEITE, 2017, p. 43) realizando, ainda, um jogo dinâmico de intervenção da imagem que não exclui o observador, pelo contrário, incomoda-o no sentido de 
ferir entranhas da representação ${ }^{5}$. Experimentando e sentindo a imagem que está entre o racional e o sensível, que subverte a tríade: criador, arte e observador, fazendo experimentações dançantes, criativas na natureza e possibilitando outras funções para o biólogo. Portanto, o que nasceu com tudo isso?

Encontros cartografados de processos elaborados em diálogos com alguns elementos encontrados na natureza: folhas, argila, rochas, fios, árvores, águas, ventos, barbantes, elásticos, entre outros, que fabulam novos diálogos com e doravante à natureza através da performance, efetuando, ainda, vibrações que ecoam biologias-outras, artes-outras, naturezas-outras para além do discurso ordenado, multiplicando-os.

Atravessamo-nos nesta pesquisa para além de um murmúrio posto à fadiga, catalisando encontros vitais como agenciamentos em devir, intensidades ${ }^{6}$, fluxos e conexões, porque devir é aliança. Possibilidades de pensar conversações entre art(e)biologia, extraindo desse "e" uma dança qualquer, suja, com cheiro de lama e gosto de guano. E, quiçá, intensificá-las sem ladainhas que cadenciam discursos, encontrando-se com potências germinadoras. É deixar ser atravessado pelo mundo que habita os mundos.

Figura 1 - Dobras monstruosas da natureza

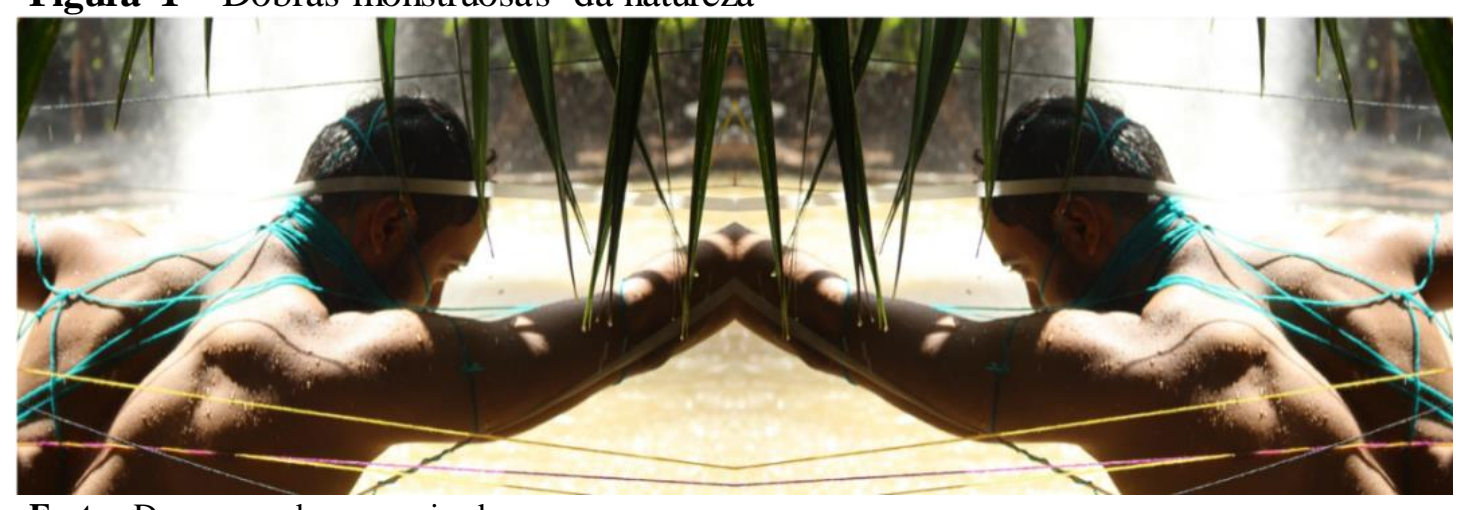

Fonte: Do acervo dos pesquisadores.

Tomamos a ideia de que a natureza não tem forma, é puro movimento, distingue-se pelas passagens que os elementos-coisas des-funcionais infinitos produzem. Trata-se de uma natureza monstruosa que é inventada e inventa-se, pondo em questão as produções de sentidos para ela que é a hibridização animal e vegetal, compondo redes de interações sistemáticas. Ora, Deleuze e Guattari (2012, p. 41) sinalizam que a natureza é 
(...) uma multiplicidade de multiplicidades perfeitamente individuada. O plano de consistência da Natureza é como uma imensa Máquina abstrata, no entanto real e individual, cujas peças são os agenciamentos ou os indivíduos diversos que agrupam, cada um, uma infinidade de partículas sob uma infinidade de relações mais ou menos compostas. Há, portanto, unidade de um plano de natureza, que vale tanto para os inanimados, quanto para os animados, para os artificiais e os naturais. Esse plano nada tem a ver com uma forma ou uma figura, nem com um desenho ou uma função. Sua unidade não tem nada a ver com a de um fundamento escondido nas profundezas das coisas, nem de um fim ou de um projeto no es pírito de Deus. É um plano de extensão, que é antes como a secção de todas as formas, a máquina de todas as funções, e cujas dimensões, no entanto, crescem com as das multiplicidades ou individualidades que ele recorta. Plano fixo, onde as coisas não se distinguem senão pela velocidade e a lentidão. Plano de imanência ou de univocidade, que se impõe à analogia. O Uno se diz num só e mesmo sentido de todo o múltiplo, o Ser se diz num só e mesmo sentido de tudo o que difere. Não estamos falando aqui da unidade da substância, mas da infinidade das modificações que são partes umas das outras sobre esse único e mesmo plano de vida.

Em Abecedário, Deleuze e Parnet (1988, p. 13) dizem que a natureza “[...] é um conjunto de dobras móveis". Sendo assim, para estes autores, a natureza sempre está na ordem das movimentações e em constantes transformações. O biólogo experimenta a natureza, seus movimentos, pois, para ele, trata-se de uma coexistência, um constituindo-se do outro, um sobre o outro, um no outro.

O biólogo mergulha nas dobras ${ }^{7}$ da natureza produzindo eco-processos ${ }^{8}$ que habitam nelas e não apenas nela, mas em outras possíveis mil-dobras. A natureza é uma multiplicidade de transformações, pois "gaia é a terra viva, é um ser de mil dobras" (LATOUR, 2014, p. 2).

Trata-se, ainda, de perceber que o biólogo não é um fora da natureza, mas é a natureza, assim como não há separação entre natureza e cultura ${ }^{9}$. Sendo assim, nessas dobras é possível pensar outras composições vitais que se reconstroem com e nas múltiplas forças, na tentativa de conexões e produção de potentes devires que são criadas com e na natureza. Por isso o biólogo desloca-se para deslocar ainda mais os ecos advindos de processos, que são ressonâncias de forças ${ }^{10}$ encontradas no experimentar com a natureza, e em contato com o(s) fora(s).

\section{Eco-processos}

Os planos de composição dos eco-processos não querem comunicar algo. Não há uma ideia que interliga comunicação e arte, pois a comunicação estaria mais na incumbência de informar, “[...] que é fazer circular uma palavra de ordem” (DELEUZE, 1999, p. 04). Deleuze, mais uma vez, subverte a ideia de arte que é pensada a partir da conjugação do verbo comunicar e transmitir, deixando-a mais leve, no entanto, resistente. 
Figura 2 - Eco-processos

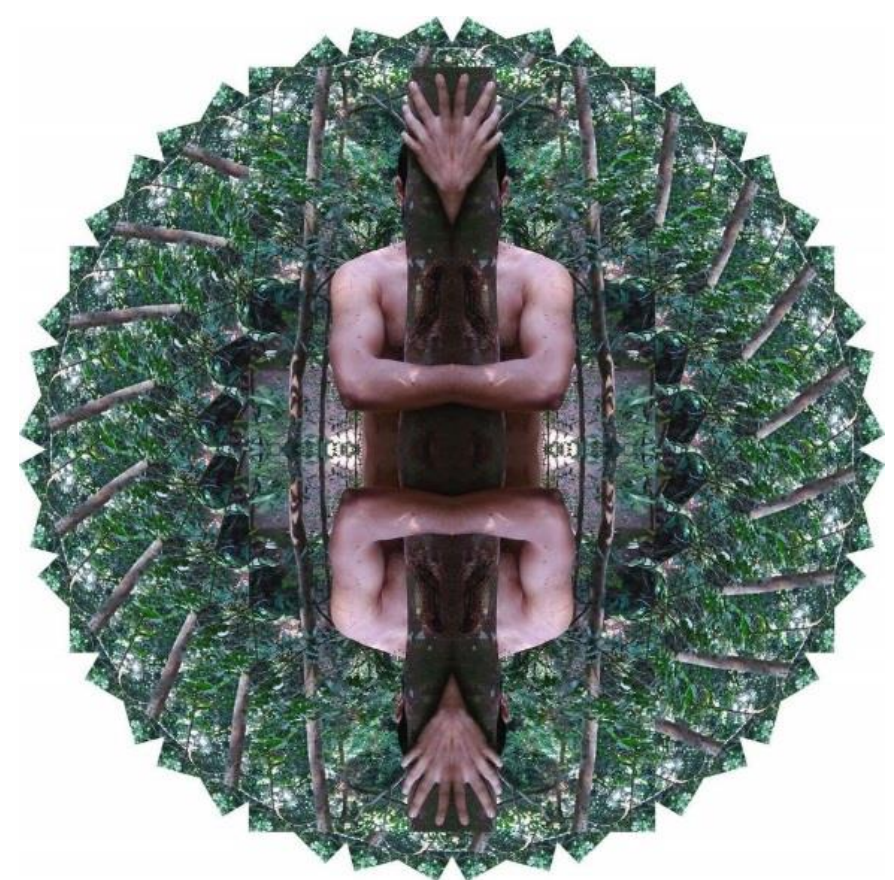

Fonte: Do acervo dos pesquisadores.

Os planos de composição dos eco-processos não querem comunicar algo. Não há uma ideia que interliga comunicação e arte, pois a comunicação estaria mais na incumbência de informar, "[...] que é fazer circular uma palavra de ordem” (DELEUZE, 1999, p. 04). Deleuze, mais uma vez, subverte a ideia de arte que é pensada a partir da conjugação do verbo comunicar e transmitir, deixando-a mais leve, no entanto, resistente.

As forças que se desdobram são poéticas e políticas. Jacques Rancière vem fundamentar seu pensamento sobre arte articulando-a à política. Rancière diz que na política há uma base estética que tenciona conceber universos possíveis, denominando-a de política da arte que tem a ver com produções ativas de "[...] ficções ou dissensos, agenciamentos de relações de regimes heterogêneos do sensível” (2005, p. 8), não para algum ato político, mas para sua própria intervenção política, pois "é realmente político não o conhecimento das razões que produzem tal ou tal vida, mas o confronto direto entre uma vida e o que ela pode" (RANCIÈRE, 2005, p. 8). Em outras palavras, trata-se de um olhar que age numa mudança de subjetividades biológicas e artísticas afogadas em modelos narrativos através do defrontar e resistir aos regimes sociais. Tais pensamentos que articulam práticas artísticas e biológicas com a resistência e buscam mais pelo invisível do que o visível; o apercebido do que o percebido; o inaudível do que o audível, para que haja a mudança dos afetos ou, então, o aumento deles. 
Figura 3-Simbioses

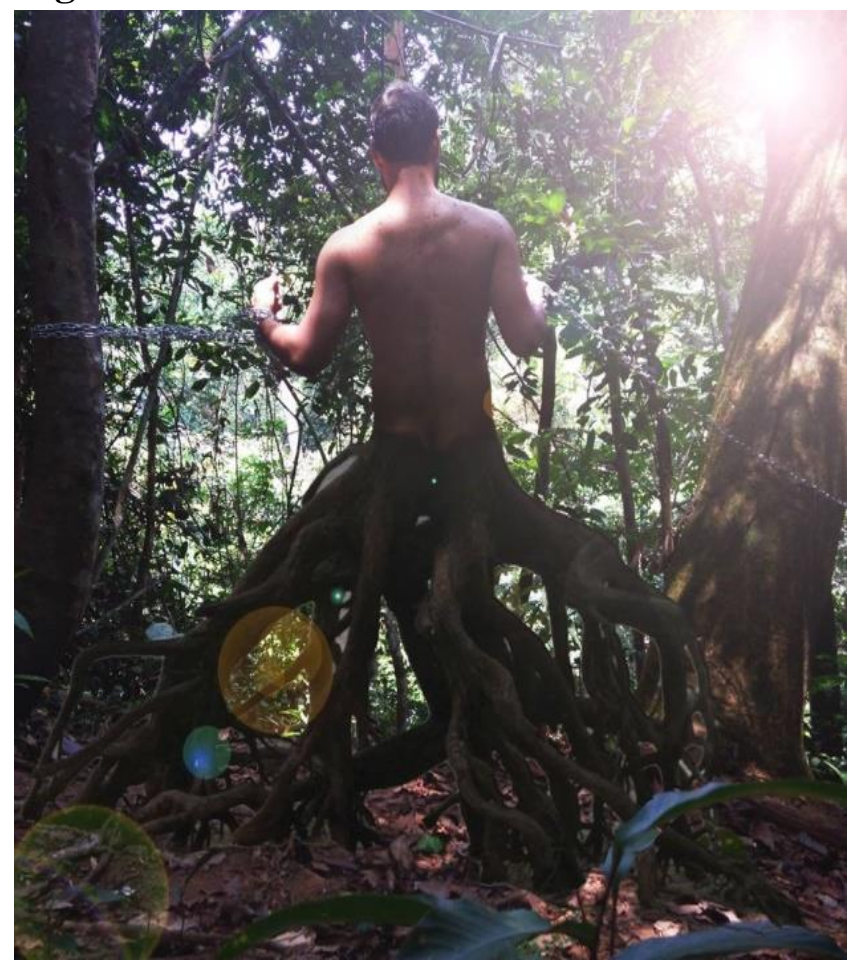

Fonte: Do acervo dos pesquisadores.

O biólogo resiste e insiste ao se metamorfosear no mundo de diferentes maneiras. Além disso, quando ele entra em contato com qualquer coisa, já não é mais aquilo, não é mais o mesmo, "não é uma concepção finalista, mas melódica, em que não sabemos mais o que é arte ou natureza", biólogo ou artista ou cartógrafo. Há, apenas, pensamentos/movimentos que transpassam coisas (DELEUZE; GUATTARI, 2013). Experimenta cisões, encontros e desconfortos que colapsam a tríade: criação, criador, contemplador.

O criador se vê sempre diante de uma situação questionante, como se ele ouvisse a voz de uma esfinge irônica, perguntando-lhe: e agora? A obra o questiona, o chama, o parasita, o explora, o escraviza, o anula - ela é um monstro! - mas ao mesmo tempo ela demanda seu testemunho, sua solicitude, inclusive para encontrar o acabamento que se insinua e que exige sempre discernir o que é factível em meio ao caos do mundo. Nenhuma intencionalidade, nenhum antropocentris mo, nenhuma mistificação da obra impossível - mas a instauração, o trajeto, a alma equivalente a uma perspectiva.(PELBART, 2017, p. 225).

Desatar a vida para a potência, para a resistência, pois resistência é humano e inumano; é criação que culmina em uma luta entre homens e outros seres no processo inventivo. Novos caminhos inventivos entre a arte e a biologia podem resistir, compor matérias sensíveis, não imitar a natureza, mas compor corpos-natureza desnaturados. Art(e)biologia em deriva que são compostas de minúsculas partículas num processo contínuo de mutação sem desunir-se por inteiro. São junções interespecíficas ${ }^{11}$. 
Simbioses-agenciamento, em que criam e trazem alianças, intensidades que compõem eco-processos entrando em simbiose. Os eco-processos são as próprias simbioses em devir, isto é, transformam-se nessa heterogeneidade que sempre está associada às simbioses, pois é ela "[...] que coloca em jogo seres de escalas e reinos inteiramente diferentes, sem qualquer filiação possível” (DELEUZE; GUATTARI, 2012, p. 15).

Simbioses sem contornos estão mergulhadas em tudo isso que consubstanciam, não para formar um monismo, mas, na multiplicidade ali presente, extraem forças heterogênicas ao compor seus ecos, pois "cada multiplicidade é simbiótica e reúne em seu devir, animais, vegetais, micro-organismos, partículas loucas, toda uma galáxia” (DELEUZE; GUATTARI, 2012, p. 35).

Pensar por agenciamentos em que a simbiose traz alianças que podem ser feitas rompidas. Intensidades que compõem art(e)biologia entrando em simbiose. A art(e)biologia e os eco-processos são as próprias simbioses ${ }^{13}$ em devir, isto é, não são pré-determinadas e nem se sabe quais serão os resultados de tais mutações gênicas, pois "cada multiplicidade já é composta de termos heterogêneos em simbiose, ou que ela não para de se transformar em outras multiplicidades" (DELEUZE; GUATTARI, 2012 p. 34).

Ao dançar pelo chão, permite-se, aqui, pensar em minoridades ${ }^{14}$ que não têm a menor utilidade, mas, que por outro lado, funcionam. Não se quer aqui desmoralizar a potência de uma arte menor: a intenção é subverter a ideia de utilidade, pois no mundo moderno as coisas são valoradas a partir da sua utilidade.

\section{Territórios-estéticos}

O biólogo andeja por muitos caminhos, e quando se perde, encontra-se, quando se encontra, perde-se novamente. É nessas velocidades e lentidões que ele também caminha por territórios-estéticos ${ }^{15}$, uma terra inventiva, que brota coisas sem um controle criativo. Deleuze, em entrevista com Parnet, diz o seguinte:

Constituir um território, para mim, é quase o nascimento da arte. [grifo nosso] Quando vemos como um animal marca seu território, todo mundo sabe, todo mundo invoca sempre... as histórias de glândulas anais, de urina, com as quais eles marcam as fronteiras de seu território. (DELEUZE; PARNET, 1998, p. 3).

Para o biólogo os animais de território são prodigiosos, não estão integrados num sistema familiar quase humano, produzem intensidades nas fronteiras desses territórios que designam o estado da arte através de linhas, cantos e cores. 
Figura 1 - Territórios-estéticos

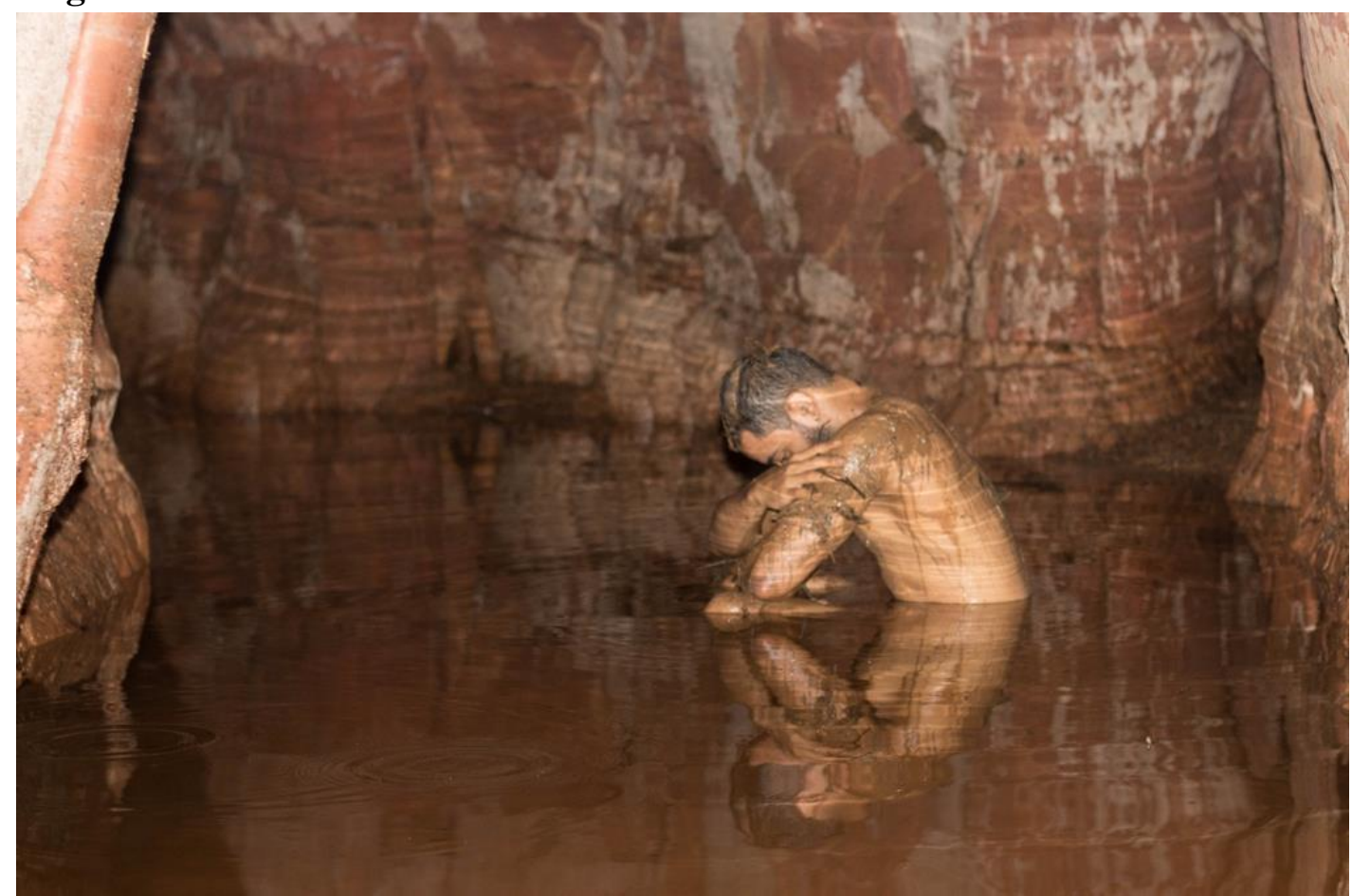

Fonte: Do acervo dos pesquisadores.

O território em si é a característica do animal, lugar onde ele se desmonta e se aventura em experimentações. Não visam um produto findado, mas penetram nos territórios-sensíveis ${ }^{16}$, do contingente e da singularidade, sempre de modo cambiante. É absorver os movimentos e as forças sem criar um produto findado em si, é mergulhar numa multiplicidade sem atribuições a um sujeito e um objeto, pois é encontrar-se "[...] numa situação, seja cotidiana ou extraordinária, que transborda qualquer ação possível ou o deixa sem reação. É forte demais, ou doloroso demais, belo demais" (DELEUZE, 2013 p. 70).

Seu corpo biológico e orgânico se decompõe para tornar-se outra coisa. Múltiplos átomos que transformaram o corpo, que o reanimaram, possibilitando, ainda, mover-se entre qualquer coisa. Partículas minúsculas que se combinam cambiando por forças da/na natureza, fabulando-se em mil dobras com o corpo, que para ele e por si só jamais existiram, pois ele não é artista ou biólogo. Criaram e continuarão a criar outras coisas — pássaros, árvores, peixes, água - uma criação sem fim. 
Figura 5 - Corpo putrificado de vida

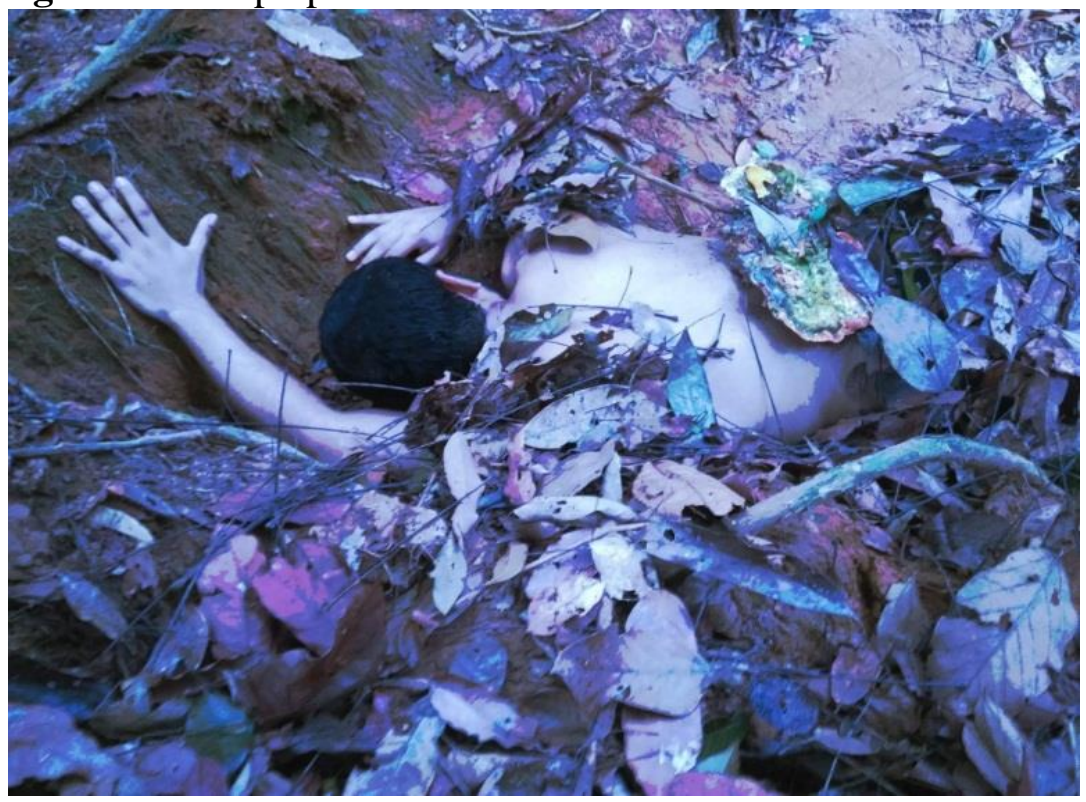

Fonte: Do acervo dos pesquisadores.

Ele dormiu corpo e acordou corpo-outro imbuído na seiva vital. Os sonhos produzidos por este sono são muito mais excitantes do que qualquer realidade acordada. $\mathrm{O}$ sonho não se finda em si, prossegue ao acorde do acordar com o canto das árvores, o grito da terra, as cores da terra, o ortiga das águas, a ardência das flores, o cheiro do ar. O biólogo que dança aqui não se comunica com o fora, perde-se com ele. Nesse choque experienciado tudo nasce como um carnaval extático que coabita uma errância inventiva, que vaza, infiltra feito uma trepadeira.

\section{Biólogo Cartógrafo}

Figura 6 - Biólogo Cartógrafo

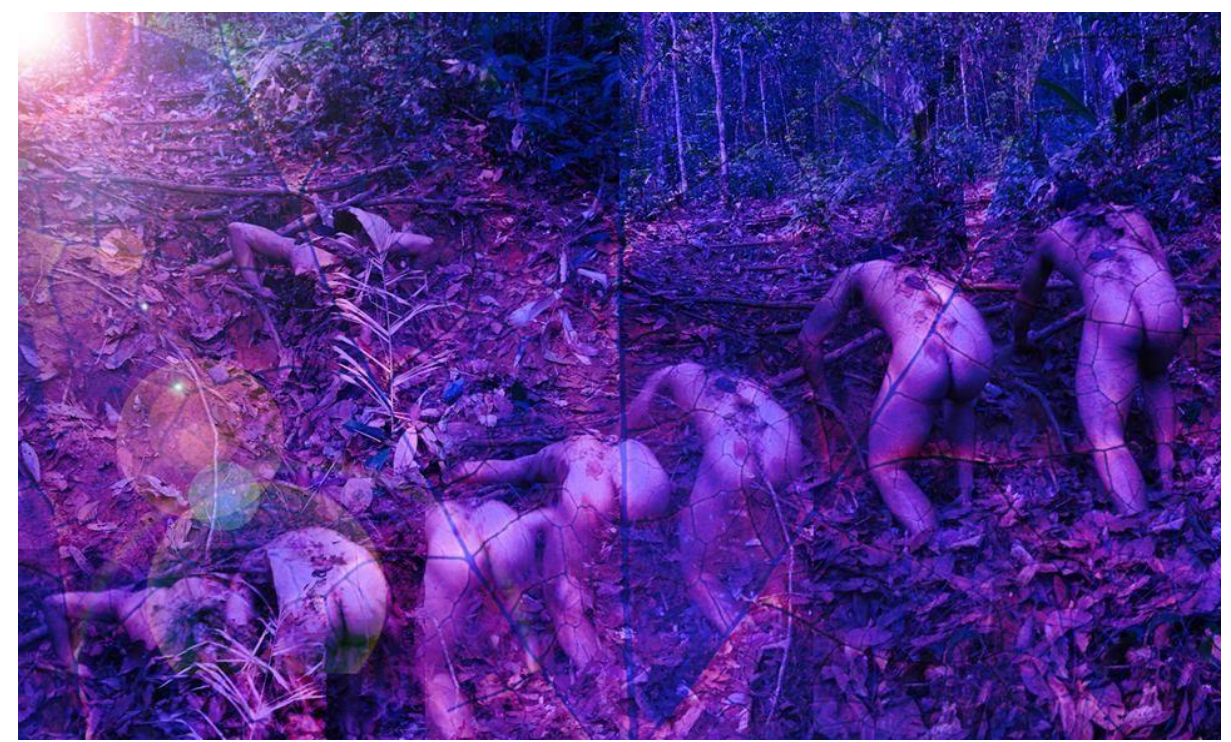

Fonte: Do acervo dos pesquisadores. 
A cartografia é um descaminho que se dá embaralhado em vários encontros que levam às problematizações, não necessariamente, de uma pesquisa. São planos de imanência intrinsicamente experienciais. A cartografia não se delimita em um método, antes de tudo, é um modo de vida. É pelo entre que a cartografia dissemina os múltiplos movimentos criados (MASNY, 2013). E é neste entre que se quer pensar a cartografia, entre art(e)biologia, entre art(e)natureza.

Sendo assim, não importa saber o "que é" essa cartografia, mas "como" a partir dela se pode experimentar meios de percorrer por uma natureza caótica. Foi nesse campo de forças experimentativas e cartográficas que o biólogo se perdeu no trajeto e nele deixou cair às racionalidades que a biologia havia forjado. Deixou cair o que o tolhia de experimentar os lugares e fazer parte deles. Optou por não seguir uma direção ou, talvez melhor, uma única direção. Optou por além de ser cartógrafo ser antropófago.

\section{Biólogo antropofágico}

Figura 2 - Biólogo antropofágico

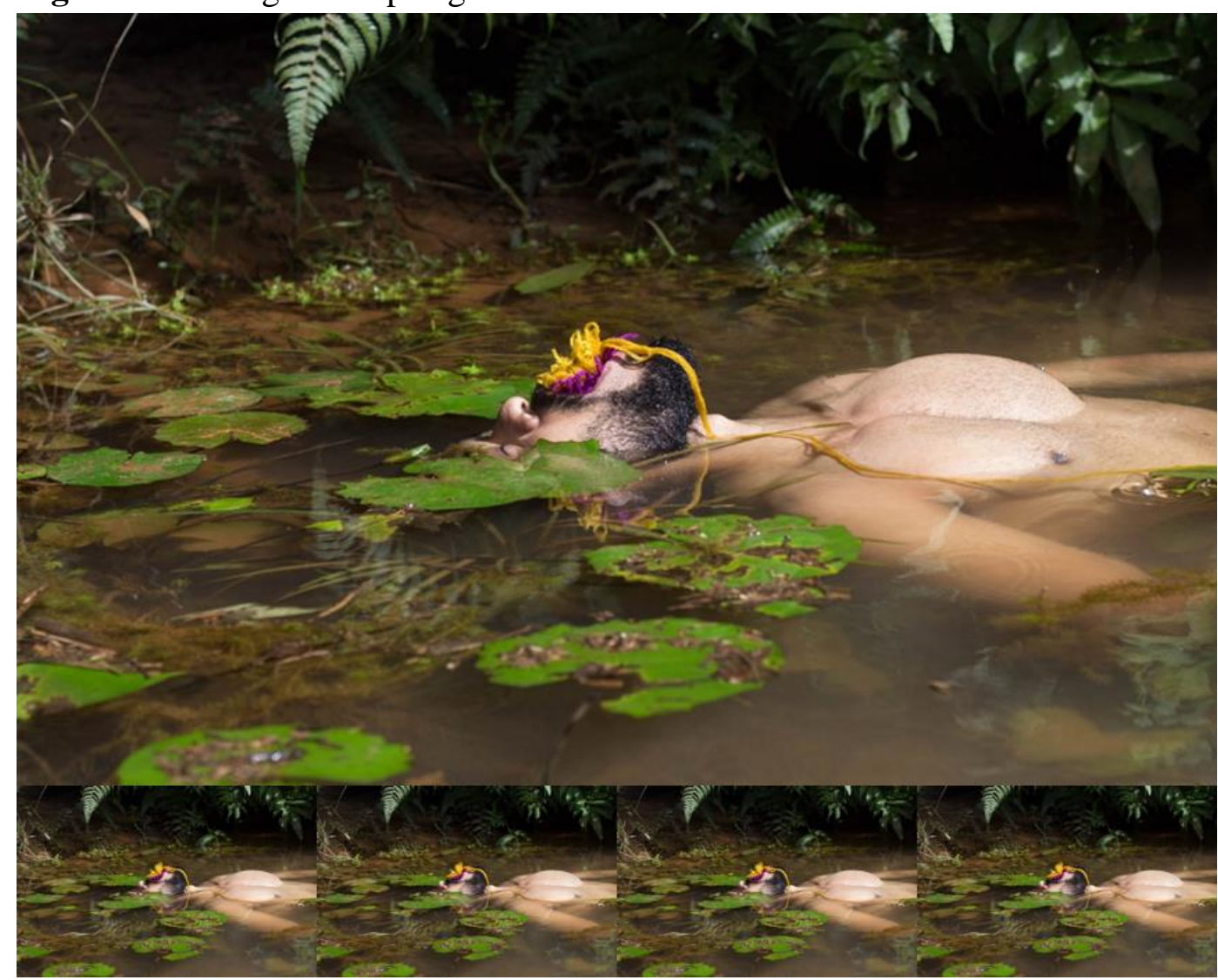

Fonte: Do acervo dos pesquisadores. 
Poderia, então, falar de um biólogo antropófago, considerando o conceito de antropofagia apresentado por Rolnik: "[...] engolir o outro, sobretudo o outro admirado, de forma que partículas do universo desse outro se misturem às que já povoam a subjetividade do antropófago e, na invisível química dessa mistura, se produza uma verdadeira transmutação" (ROLNIK, 1996, p. 10).

Todo esse processo faz lembrar dois episódios contados pela autora sobre a cultura brasileira, mais precisamente, sobre o canibalismo indígena. O primeiro é sobre os índios Caeté que cozinharam os pedaços do primeiro bispo do Brasil, chamado Sardinha, junto com 90 tripulantes que estavam com ele, os quais vieram com o intuito de catequisar os índios, contudo, morreram em um naufrágio.

Na mesma perspectiva, a autora fala do desbravador Hans Staden que foi capturado por índios Tupinambá que, por sua vez, preparam-no para devorá-lo num ritual, no entanto, desistiram pela falta de valentia do desbravador. Os índios buscavam muito mais que matar a fome através do ritual: tomavam para si os atributos do alimento. Ambos os casos tratam de rituais antropofágicos realizados pelos índios no Brasil Colonial através de cerimônias coletivas nas quais devoravam os inimigos, no entanto, não podia ser qualquer um.

O costume antropofágico também era percebido com os Yanomami, porém, entre os habitantes de uma mesma tribo, este povo ingeria as cinzas de entes queridos por amor, respeito e carinho, não por meio de ritual brutal como os dos Tupinambá e Caeté. Muito mais do que devorar carnes, o ritual antropofágico é tomar para si a função vital do outro (ROLNIK, 1996), seus universos dos mais variados, "a arte do impossível, a arte de atravessar espelhos, de devir: metamorfose invisível" (CASTRO, 1986, p. 618). À vista disso, trouxemos essa ideia com o intuito de movimentar o biólogo que se alimenta dessas coisas da natureza e se compõe com elas, transforma-se nelas e elas nele. O biólogo entra em devir.

\section{Biólogo e o devir animal}

O biólogo entrou em devir, que não se trata dos "fenômenos de imitação nem de assimilação, mas de dupla captura, de evolução não paralela, de núpcias entre dois reinos" (DELEUZE; PARNET, 1998, p.10). Devir animal, selvagem, arbitrário, que não segue regras ou condutas domesticadoras. Devir animal jamais é imitar o cachorrinho ou o gatinho. Seu êxtase é o agenciamento de multiplicidades, pois lá as alianças serão construídas para devir animal; agenciar é o que o devir animal faz, sendo assim é "precisamente fazer o movimento, traçar a linha de fuga em toda a sua positividade, ultrapassar um limiar, atingir um continuum 
de intensidades que só valem por si mesmas, encontrar um mundo de intensidades" (DELEUZE; GUATTARI, 1977, p. 27).

Elizabeth Grosz, em seu artigo A arte e o animal, diz que "a arte é do animal (...) o que há de mais artístico em nós é também o mais bestial". A arte tem muito a ver com o caos e não o limita, não o desacelera (DELEUZE; GUATTARI, 2013), são zonas de indeterminações, isto é, de transformações, e é nela que todos os devires se proliferam inclusive o devir animal. É o que problematiza Grosz (2012, p. 122) "os animais são artísticos?”.

Certamente há muito mais relação entre o devir animal e devir-artístico e se sabe que esses devires proliferam intensidades, forças que as fazem vazar pelos muros claustrofóbicos no encontro de experimentações.

\section{Figura 3 - Biólogo e o devir animal}

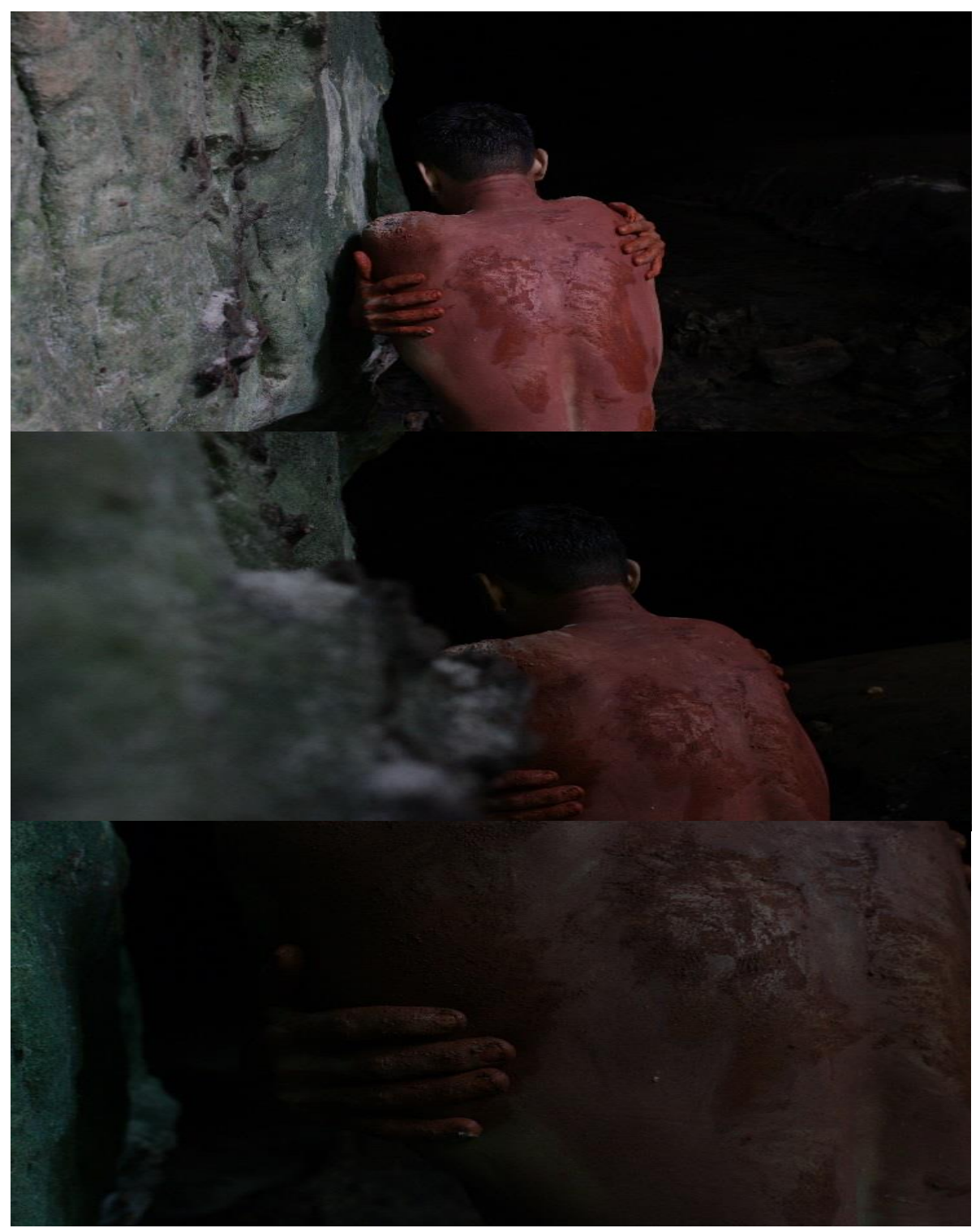

Fonte: Do acervo dos pesquisadores. 
Deleuze e Guattari vaticinam que "a arte começa talvez com o animal, ao menos com o animal que recorta um território e faz uma casa (os dois são correlativos ou até mesmo se confundem) (2013, p. 217)”. Estes dizeres sugerem um embaraçar entre o animal, o território e a própria arte. Devir animal não é deseducar-se, é tornar-se imbuído numa multiplicidade avassaladora: briga ferozmente por comida e pelo seu território, está em constante movimento. No entanto, o biólogo não pode estar sempre articulado aos devires-animalescos; é uma passagem pelo inferno, uma "realidade demoníaca do devir animal do homem" (DELEUZE; GUATTARI, 2012, p. 39). São risadas demoníacas que queimam e avivam o caos, por isso, talvez, todo devir é intenso e ressona dos encontros alegres.

O biólogo, nas suas andanças, encontrou alguns seres inventados por ele. Não se quis catalogar ou ao menos descrever, como faz (muito bem) Jorge Luis Borges em seu livro dos seres imaginários. Deixo para que o leitor desfrute desses seres im-possíveis e, caso queira, invente suas próprias descrições.

Figura 9-E. Entreins

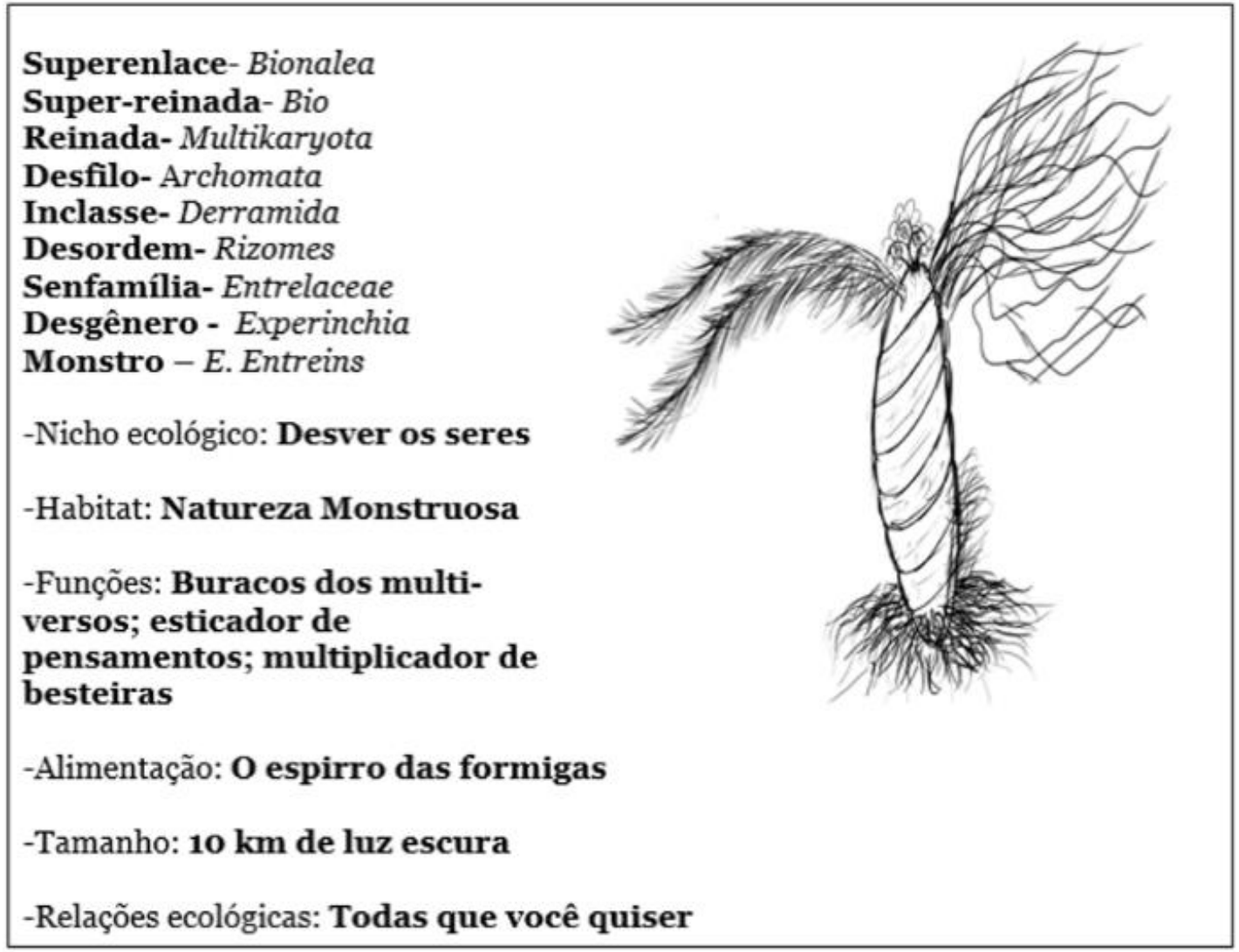

Fonte: Do acervo dos pesquisadores. 
Figura $10-E$. fabuleins

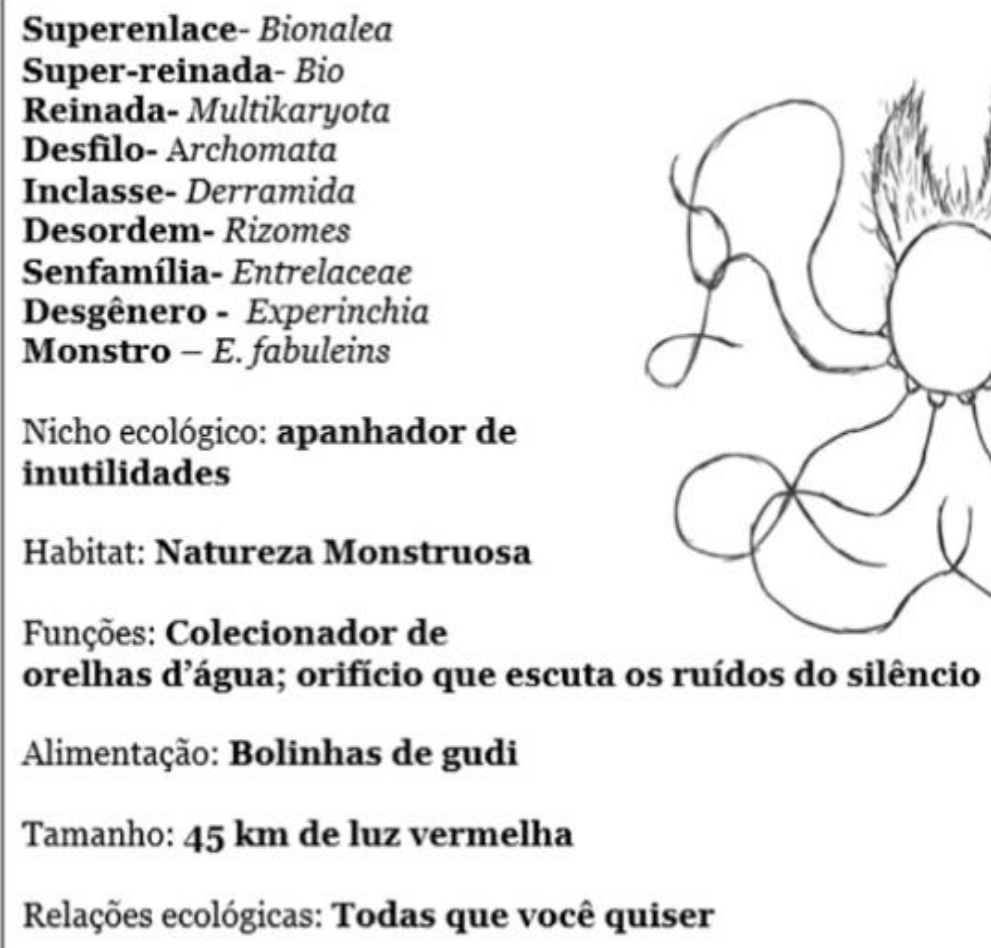

Fonte: Do acervo dos pesquisadores.

Todas as experimentações vivenciadas pelo biólogo, perpassando por art(e)biologia, eco-processos, simbioses, territórios-estéticos, bem como todos os biólogos criados a partir das relações estabelecidas foram, na sutileza dos encontros proporcionados pela natureza e seus "desperdícios", formas de conectar-se com a natureza a fim de criar corpos, abandonar o corpo em putrefação e trazer outra energia corroborando, também, numa outra educação.

Poderia a natureza, como um ecossistema, ser um laboratório do corpo e das sensações para a educação? Como a art(e)biologia se cruza com e na natureza e o que se compõe nesses vazamentos, nessas relações, que educações podem ser multiplicadas e inventadas a partir dessa outra natureza?

\section{Alguns apontamentos finais para a educação}

A educação acontece na vida. Sendo assim, que educação desperta no entre biologia e arte? Ousamos responder essa pergunta a partir de uma proposta alegre para um ato de educar mais sensível e que não só transita entre os saberes, mas busca criá-los, não a fim de substituir um saber mais antigo, porém, quem sabe, compor junto por uma art(e)biologia que nos possibilite rir na educação. 
Stengers (2002, p.29) diz interessar-se, especialmente, sobre a "qualidade do riso" permitindo-nos discutir sobre a possibilidade de uma biologia alegre na educação. Uma biologia que não existe, apenas acontece. Uma educação científica a qual é muito mais do que o medo que, ao disciplinar, paralisa. Afinal, a biologia produz risos? Quais risos? Medos? Quais medos? Coisas? Quais coisas?

A biologia nunca deixou de produzir seus risos. É no devir molecular que essa alegria aparece e se reinventa. O riso, aqui, nada tem a ver com o bom humor, muito menos com um gesto facial expressado a partir dos lábios. Não é a transmissão de algo que somos. Não é pensar a alegria como o oposto da tristeza, pois quanto maior a tristeza, maior a alegria que repousa nela. São sorrisos intercalados com choros que produzem sons, que denotam ruídos imbuídos em acontecimentos e multiplicidades, habitando toda uma atmosfera de forças e intensidades.

Pensando com Espinoza (2009), os bons encontros ressoam em sorrisos, que aumentam a potência do corpo através de afetos alegres. É quando se está sozinho, num prédio escolar velho, sujo e se é lançado na pior das salas, sendo atravessado por afetos tristes, que diminuem sua potência de aprender, afetar, ser afetado, de viver. Repentinamente, escuta-se um pequeno barulho seco na madeira da porta, um novo encontro brota contingente e alegre. Logo, tudo pode ser transmutado: o cheiro muda, o ar some, as cores nascem e tudo se torna outro, diferente, sorridente, apenas com um gesto sensível.

Diante disso, a pergunta inspirada em Espinoza é, então, como desviar-se da tristeza, e, nela, produzir paixões e ações alegres? Trata-se de agitações interrogativas de difícil resposta, principalmente, quando a sociedade está constituída de cidades cinzas e tristes, as quais reverberam escolas intransigentes e, logo, em biologias rígidas que objetivam a produção de cópias, a generalização das coisas e a supressão do que as difere. Entretanto, não é só disso que a educação e a biologia são compostas; elas também produzem seus bons encontros que nos possibilitam respirar, mesmo que em poucos minutos, o oxigênio vital do sorriso alegre. Por isso, que encontros podem produzir a biologia? Ou melhor, quais sorrisos um encontro produz na biologia?

Uma biologia sorridente pode valer muito mais do que toda cientificidade das ciências modernas. Não custa dinheiro e pode criar mundos possíveis. Um sorriso dura um segundo e, também, uma eternidade. Um sorriso pode significar tudo e, ao mesmo tempo, nada. Fazer a biologia sorrir, transformar, mudar.

Risos que não delineiem a biologia, ou que sejam conduzidos por suas expensas, mas que sejam partilhados pelos pequenos movimentos que fazem existir outras existências. Diante disso, compartilho com Isabelle Stengers sobre a potência do riso: 
Não quero um riso de troça ou um riso que seja de desprezo, da ironia que identifica sempre e sem risco o mesmo para além das diferenças. Eu gostaria de tornar possível o riso de humor que compreende, aprecia sem esperara salvação e pode recusar sem se deixar aterrorizar. (STENGERS, 2002, p.29, grifos nossos).

As ideias salvacionistas e aterrorizantes, as quais Stengers problematiza sobre a ciência, são utilizadas e pensadas como artefatos de conduta para uma possível salvação da sociedade. São discursos sobre a ciência (ou biologia) que fabricam coisas e promovem práticas. É uma ideia messiânica do cientista, o qual cinge-se e é cingido pela grande responsabilidade de salvar os corpos não cientistas e, consequentemente, o mundo em que interagem. Muitas vezes, esses discursos científicos são pensados de maneira aterrorizante, em que a ciência deve ser tratada como uma pedagogia disciplinar. Um espaço que aprisiona e através do controle de corpos se torna forte o suficiente para moldar, através do medo e do castigo, as reações no mundo.

Não basta "denunciar" essa perspectiva científica da biologia; não basta trancafiá-la e soltar outra "melhor"; não basta assassiná-la. Quem sabe, talvez, fender os sentimentos de impotência, medo e tristeza que ameaçam a capacidade de existir, resistindo ao que aprisiona e faz chorar. Entretanto, não é o riso alegre o fator chave que fará da biologia um artefato centralizador de mudanças extraordinárias de algo ruim, para algo bom, aliás, não é isso que queremos; os risos perturbadores não são e nunca serão suficientes, mas promovem levezas, pois sem os sorrisos conferem-se destinos predeterminados, nada inventivos. Sem os sorrisos os jogos de poderes podem definir os futuros, as condutas e tudo aquilo que aprisiona as alegrias vindouras de uma biologia qualquer.

A luta política que produzimos na escrita, na produção de imagens e no pensamento não perpassam pela ideia de uma biologia oficial e sim pela criação de $\operatorname{art}($ e)biologia no mundo; que façam experiências de/com uns, de/com outros, de/com coisas, mesmo reconhecendo a importância das narratividades racionais da biologia. Buscamos escutar e produzir risos na biologia, que soam como cantos entoados numa estação que não é nem outono, inverno, primavera ou verão. É um riso que afugenta melodias brotadas das trevas e das luminescências de uma biologia que, conforme foi dito, simplesmente acontece, é contingente.

A art(e)biologia produz alegrias, signos e encontros que se deslocam por meio de rastros esquecidos, porém, fortes o suficiente para arrebentar paisagens arquitetônicas que apresentam atmosferas rígidas e legitimam sistemas homogêneos que sufocam.

Pensando a modo de Deleuze e Guattari, a art(e)biologia é concebida a partir de tessituras menores ${ }^{17}$. São resíduos de um entre constituídos menos por trajetos fixantes e fixadores, do que por labirintos barrentos, que possibilitam se perder em meio às heterogeneidades que compõem os saberes. Deslocando o pensamento baseado nos autores 
citados é uma desterritorialização que desloca os trâmites científicos, agenciamentos que se dão imergidos em multiplicidades de vidas e cores e um ato político que de prática didática ou pedagógica como modelo tem pouco: é mais relacionado às desobediências que fissuram as já mencionadas arquiteturas da ciência maior.

Assim, acreditamos em uma parceria entre arte e biologia, uma art(e)biologia na educação que não se preocupa apenas em compreender os conceitos e procedimentos das ciências biológicas, mas fazer dela uma passagem, um atravessamento criativo.

\section{Notas}

1. Marcelo Moscheta, obras disponível em: 〈https://www.marcelomoscheta.art.br/>; Walmor Corrêa, obras disponíveis em $\langle$ http://www.walmorcorrea.com.br/> .

2. Para maior esclarecimento dos termos, possíveis substituições do Ser pelo Devir e do É pelo E (Mil Platôs v1 e v3; Diálogos; Cinema).

3. Os dois nada têm a ver com percepção ou afeição, características que os limitariam a um sujeito/objeto e denotariam racionalização. Todavia, é sensação e devir, não no sentido de tornar-se a ser algo, mas pura captura, pois quando a arte produz as sensações derivadas dos perceptos e afectos, muda o indivíduo e a arte, é uma mudança constante, repetidamente e sempre diferente principalmente em relação às intensidades. Força, Sensação e devir-sensível são conceitos importantes para entender os perceptos e afectos (DELEUZEU; GUATTARI, 2013). Por isso, a arte captura as forças, e não as reproduz, reinventa-as e desencadeiam blocos de sensações que foi instituído através, também, dos perceptos e afectos criados pela arte e pelo artista. Definir um percepto ou afecto através da pergunta "o que é?" não seria o mais interessante, talvez, lançar mão de perguntas “o que quer?" ou "o que pode?” estaria desvencilhando mais à problematização.

4. As imagens podem ser pensadas como anamorfoses impossíveis, no sentido das sensações e devires causados pelos perceptos e afectos, não em um sentido representativo, porém, em movimentações que borram as formas. Imagens que não encerram o pensamento pensado, assim, abrem-se para novas possibilidades, rompendo com o regime da representação, regime este que lança mão da identidade em detrimento da diferença. Imagens associadas diretamente aos encontros e afetos, sendo que o segundo se dá pela contingência, através de múltiplos encontros não ordenados, "o afeto é a variação contínua da potência de agir de alguém” (MACHADO, 2009, p. 69). Com Rancière o contato, a troca, a alteridade se embaraça e compõe as imagens, não de maneira unívoca ou simples, entretanto, imagens que são as próprias performances, "não se remetem a nada além delas mesmas. Isso não quer dizer que elas sejam, como se falam comumente, intransitivas" (RANCIÈRE, 2012, p. 11). A intenção não foi interpretar, mas, quem sabe, perceber acontecimentos irrepresentáveis. Foram imagens trazidas como eco-imagens, e não apenas como registro pictográfico que atarracam o sentido normal das ideias e das figuras. Jamais querer explicá-las. Cada imagem, cada gesto é uma possibilidade de entrada para um mundo sem formas rígidas dos pensamentos sem seguir modelos estabelecidos, é um pensar flexível. As imagens penetram vidas e, ainda, podem impor sentidos, condutas que ao mesmo tempo estão presas numa malha mercadológica e comunicativa, são palavras articuladas que, a partir da linguagem, tentam dizer o que é a imagem; imagens como diz Pelbart, (2017, p.253) "domesticadas à linguagem, imagens subordinadas à comunicação, imagens tomadas num sistema de troca ou da mercadoria [...]. A imagem repleta de intenções, de cultura". Nesse sentido, pensamos naquelas imagens que viajam em direção ao mar, não as que permaneçam nele. São imagens vazias, não no sentido da desvalorização, mas, ainda, imagens que promovem acontecimentos, os quais, a partir dos encontros, fabricaram novas intensidades que existem na medida em que fazem existir, também, outras imagen s que ampliam novas atmosferas existenciais, onde nada se via, nada se sentia, é possível criar e romper as formas imagéticas.

5. No livro Diferença e Repetição, Deleuze critica a imagem do pensamento dogmático (pensamento por imagens) que está atrelada à representação. O filósofo sugere que vivemos em uma civilização do clichê, e apresenta pensamento sem imagem, que mais tem a ver com a diferença, que viabiliza passagens, movimentos, experimentações vitais, escapando das formas solidificadas e criando modos de existência.

6. Para Deleuze e Guattari, as intensidades são singularidades.

7. O termo dobra nas suas diversas configurações (dobrar, dobrando, dobrado) aparece com bastante frequência no livro $O$ que é filosofia? de Gilles Deleuze e Félix Guattari, quase sempre associado a movimento (p. 49, 62, 65, 93, 109, 229...), que nada tem a ver como duração temporal, mas com diferença conforme sinaliza Takayama (2014, p. 273), os movimentos não estão nas coisas, as coisas que estão em movimento. "O movimento insufla vida e novidade na matéria/imagem/arte" (p. 267). Abandonamos o termo obra, pois em momento algum pretende-se estratificar ou cristalizar todo o agenciamento artístico proposto. Prefere-se o processo, que acontece na entre-dobras da natureza. 
8. Tais movimentos são denominados de eco-processos, que são abalos que cambiam por entre imagens-forças que aqui se desdobram na natureza.

9. Natureza e cultura tornaram-se dois elementos estritamente opostos. Dois polos distantes sem conexões entre si. Quando falamos de natureza, logo nos vem à mente as plantas, pedras, cachoeiras, animais, lagos, flores, rios, mares, entre outros. Elementos que juntos compõem a natureza, cuja origem é pensada sempre a partir de um processo naturalista, seja por meio de um criador divino, como defende os religiosos, ou produto do acaso como relativizam os defensores do evolucionismo. Ambas as correntes encontram semelhanças ao colocar a natureza como algo que está dado. Não há sobre o homem um poder inventivo com a natureza (DE AMORIM; GONÇALVES, 2014).

10. Vale ainda pensar "ora as forças se fundem umas nas outras em transições sutis, decompõem-se e logo são vislumbradas, ora se alternam e se enfrentam. Ora deixam-se selecionar pelo território, e são as mais benevolentes que entram em casa. Ora lançam um apelo misterioso que arranca o habitante do território. Ora lançam um apelo misterioso que arranca o habitante do território, e o precipita numa viagem irresistível (...). Ora se abatem sobre o território e o invertem, malevolentes restaurando o caos de onde ele mal saía" (DELEUZE; GUATTARI, 2013 p. 220)

11. Termo que foi mencionado no livro $O$ que é filosofia? na página 219 , em que os autores estão sempre associando arte e natureza com a multiplicidade, um território com planos e extensões.

12. As simbioses são curiosas, pura heterogênese. Art(e)biologia e eco-processos inventam com as simbioses e as forças que delas retiram, portanto, as pontes-devires são construídas para facilitar as conexões, vale ressaltar que não se sabe onde uma ponte-devir irá surgir, ela apenas nasce, com suas forças, cruzamentos, inserindo uma coisa na outra, entrelaçando os sentidos, transformando as lógicas, os sistemas.

13. Na obra de Kafka Por uma literatura menor, Deleuze e Guattari problematizam o conceito Menor.

14. Esse termo territórios-estéticos teve bastante influência a partir da filosofia de Deleuze e Guattari, principalmente no livro $O$ que é filosofia? que é quando os autores se debruçam nas páginas 219 a 220 sobre o território da natureza, principalmente sua relação com a arte. Os territórios-estéticos têm menos a ver com lugar do que com desterritorialização, sendo que este último é o que mais lhe compõe como um campo de movimentos caóticos que exprimem criações sempre do diferente. Os territórios-estéticos são o caos circunscrevendo o cosmos em criação que ecoa: simbioses, processos, dobras, todo tipo de movimentação fabuladora. Neles, o caos é bem-vindo, atrelado à resistência, onde se produz artefatos/comunidades sensíveis que não se determina por lei ou pelo poder do Estado.

15. Produção de um novo corpo destinado a algo que não é a exploração, um corpo destinado a luta coletiva, corpos/olhares livres e desinteressados. Programa completo de transformação da vida coletiva, com vista a reinstituir a não distinção ou não separação entre arte e vida (bio). Os eco-processos se potencializam nos territórios-estéticos, onde "muitas funções orgânicas se transformam, sexualidade, procriação, agressividade, alimentação, mas não é essa transformação que explica a aparição do território e da casa; seria antes o inverso: o território implica na emergência de qualidades sensíveis puras, sensibilia que deixam de ser unicamente funcionais e se tornam traços de expressão, tornando possível uma transformação das funções" (DELEUZE; GUATTARI, 2013 p. 219).

16. Para saber mais sobre as problematizações do conceito menor ver Por uma literatura menor, e ciência menor, Mil Platôs volume 5, ambas obras de Deleuze e Guattari. 


\section{Referências}

CAMPOS, R. A. Arteciência: afluência de signos co-moventes. São Paulo: Perspectiva, 2003.

CASTRO, E. B. V. Os deuses canibais: a morte e o destino da alma entre os Arawete. Revista de Antropologia, v. 27, n.3, 1984.

DE AMORIM, A. C. R.; GONÇALVES, M. L. C. M. R. Naturezas artificiais e a diferença paradoxal entre ciências e culturas. Interacções, v. 10, n. 31, 2015.

DELEUZE, G. A literatura e a vida. In: Crítica e clínica. São Paulo: Editora 34, 1997.

DELEUZE, G. Conversações. São Paulo: Editora, 34, 2013.

DELEUZE, G. Diferença e repetição. Rio de Janeiro: Graal, 2006.

DELEUZE, G. A imagem-tempo. São Paulo: Brasiliense, 2007.

DELEUZE, G. O ato de criação. Folha de São Paulo, 1999.

DELEUZE, G; GUATTARI, F. Mil Platôs. Vol. 1. São Paulo: Editora 34, 2012.

DElEuZE, G; GUATTARI, F. Mil Platôs. Vol. 3. São Paulo: Editora 34, 2012.

DELEUZE, G; GUATTARI, F. Mil platôs. vol. 4. São Paulo: Editora 34, 2012.

DELEUZE, G; GUATTARI, F. Mil Platôs. Vol. 5. São Paulo: Editora 34, 2012.

DELEUZE, G; GUATTARI, F. O que é a filosofia. São Paulo: Editora 34, 2013.

DELEUZE, G; GUATTARI, F. Kafka: por una literatura menor. São Paulo: Imago Editora, 1977.

DELEUZE, G; PARNET, C. O abecedário de Gilles Deleuze: transcrição integral do vídeo, para fins exclusivamente didáticos. São Paulo: Éditions Montparnasse, 1988.

DELEUZE, G; PARNET, C. Diálogos. São Paulo: Editora Escuta, 1998.

DIAS, S. O; ANDRADE, E. C. P; DE AMORIM, A. C. R. (Org.). MultiTÃO: experimentações, limites, disjunções, artes e ciências. 1. ed. Feira de Santana, Brasîlia. Editora da UEFS, CNPq/MCTI e ALB, 2012.

DIAS, S; RODRIGUES, C. Transes. E se artes e ciências? E se ...e ...? Leitura: teoria \& prática, v. 1, n. 59, 2012.

ESPINOSA, B. Ética. Belo Horizonte: Autêntica, 2009. 
GROSZ, E. A arte e o animal. In: Susana Oliveira Dias; Davina Marques; Antonio Carlos Amorim. (Org.). Conexões: Deleuze e Arte e Ciência e Acontecimento.... $1^{\mathrm{a}} \mathrm{ed}$. Rio de Janeiro: De Petrus, 2012.

HISSA, C. E. V. Conversações de artes e de ciências. Belo Horizonte: Editora UFMG, 2011.

LATOUR, B. Bruno Latour, antropólogo e escritor: "Temos que reconstruir nossa sensibilidade" (Entrevista concedida a Luiz Felipe Reis). O Globo, Rio de Janeiro, 29 set. $2014 b$.

LEITE, A. Manipularte. Revista ExperimentArt, v.1, n. 1, 2017.

MACHADO, R. Deleuze, a arte e a filosofia. Rio de Janeiro: Zahar, 2009.

MASNY, D. Cartographies of becoming in education: a Deleuze-Guattari perspective. Qualitative Research in Educacion, v. 1, n. 3, 2013.

PELBART, Peter Pál. Por uma arte de instaurar modos de existência que "não existem". Como falar de coisas que não existem. led. São Paulo: Bienal de São Paulo, v. 1, p. 250-265, 2014.

RANCIÉRE, J. O destino das imagens. Lisboa: Orfeu Negro, 2012.

RANCIÉRE, J. Política da arte. São Paulo: Sesc-SP, 2005.

ROLNIK, S. Esquizoanálise e Antropofagia. Cadernos de Subjetividade, v. 4, n. 1, 1996.

SILVA, A Laboratórios dos Despropósitos: vestígios ecológicos entre arte e ciência. 2018. Tese (doutorado) - Universidade Estadual de Campinas, Faculdade de Educação, Campinas, SP, 2018.

STENGERS, I. A invenção das ciências modernas. Editora 34, 2002. 